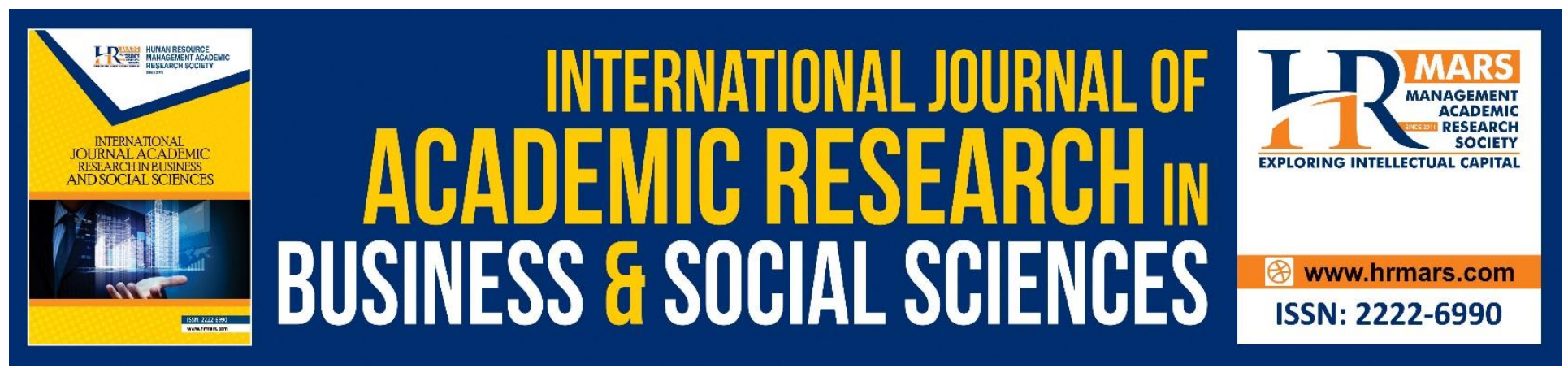

\title{
Constitutional Structure of Indonesia Based on 1945 Constitution before and after Amendments
}

Bambang Panji Gunawan, Abdul Majid Tahir Mohamed, Mahbub Dhofir, Amrizal Hamsa

To Link this Article: http://dx.doi.org/10.6007/IJARBSS/v8-i9/4543

DOI: $\quad 10.6007 /$ IJARBSS/v8-i9/4543

Received: 17 July 2018, Revised: 23 August 2018, Accepted: 29 August 2018

Published Online: 29 September 2018

In-Text Citation: (Gunawan, Mohamed, Dhofir, \& Hamsa, 2018)

To Cite this Article: Gunawan, B. P., Mohamed, A. M. T., Dhofir, M., \& Hamsa, A. (2018). Constitutional Structure of Indonesia Based on 1945 Constitution before and after Amendments. International Journal of Academic Research in Business and Social Sciences, 8(9), 33-40.

Copyright: (c) 2018 The Author(s)

Published by Human Resource Management Academic Research Society (www.hrmars.com)

This article is published under the Creative Commons Attribution (CC BY 4.0) license. Anyone may reproduce, distribute, translate and create derivative works of this article (for both commercial and non-commercial purposes), subject to full attribution to the original publication and authors. The full terms of this license may be seen

at: http://creativecommons.org/licences/by/4.0/legalcode

\section{Vol. 8, No. 9, September 2018, Pg. 33 - 40}

Full Terms \& Conditions of access and use can be found at http://hrmars.com/index.php/pages/detail/publication-ethics 


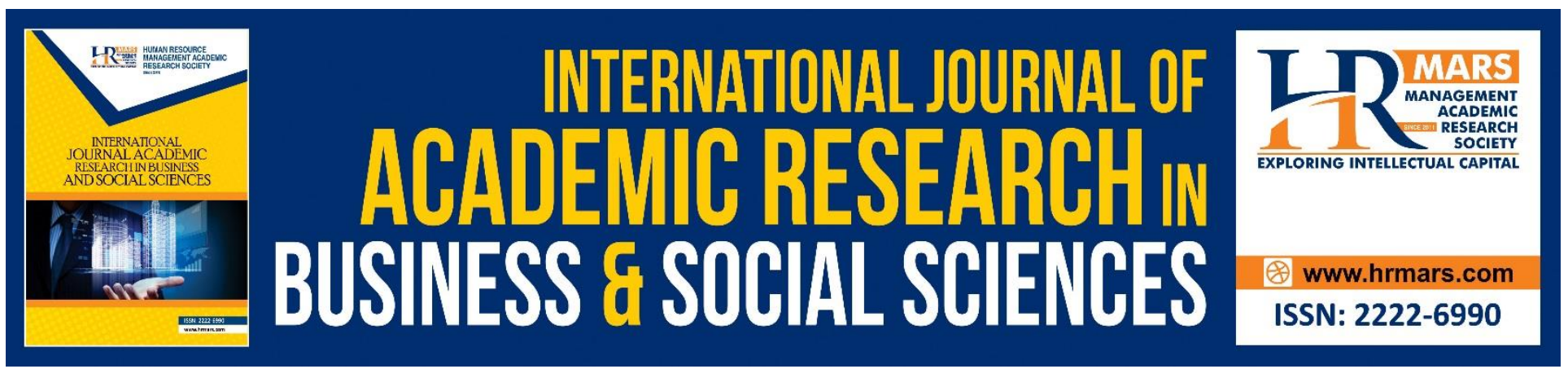

\title{
Constitutional Structure of Indonesia Based on 1945 Constitution before and after Amendments
}

\author{
Bambang Panji Gunawan ${ }^{1}$, Abdul Majid Tahir Mohamed ${ }^{2}$, Mahbub \\ Dhofir ${ }^{3}$, Amrizal Hamsa ${ }^{4}$ \\ ${ }^{1}$ Lecturer University of Maarif Hasyim Latif, Surabaya, Indonesia \& Ph.D. Student at Faculty of Law, \\ Universiti Sultan Zainal Abidin, Terengganu, Malaysia \\ ${ }^{2}$ Faculty of Law, Universiti Sultan Zainal Abidin, Terengganu, Malaysia \\ ${ }^{3}$ Faculty of Law, Universitas Gadjah Mada, Yogyakarta, Indonesia \\ ${ }^{4}$ Faculty of Law and Islamic Finance, Sekolah Tinggi Agama Islam (STAIN) Teungku Dirundeng \\ Meulaboh, Indonesia
}

\begin{abstract}
Article 1 (3) of the 1945 Constitution states that "Indonesia is a country of law." The provision of the article is a constitutional basis that Indonesia is a state based on law. Law is placed as the only rule in the life of society, nation, and state (supremacy of law). Before the amendment of the 1945 Constitution, Indonesia is a country based on law, contained in the preamble, the 1945 Constitution body. A statement that Indonesia is a country of law can also be seen in the 1945 explanation. Applicability of 1945 before and after the amendment is followed by different constitutional structure, which will give different meaning as a based on law state. In Continental European legal systems, rechtsstaat legal state building is known. Meanwhile, other parts of the world, the concept of the rule of law state extracted from Anglo Saxon states. Both laws state models prioritize different aspects. Rechtsstaat concept prioritizes wetmatigheid principles which later becomes rechtmatigheid. Meanwhile, the rule of law prioritizes equality before the law. Due to differences in emphasis in these operations, there arose the different elements between rechtsstaat concept and the rule of law concept.
\end{abstract}

Keywords: Constitutional Structure, Constitution Amendment, Indonesia

\section{Introduction}

Reformation taking place in Indonesia in 1998 has led to a very big change for the nation including in administration of Indonesia. One of the reformation outcomes in the field of administration is four times amendment of the 1945 Constitution. Since the promulgation of Presidential Decree on July 5 , 1959 , on the re-enactment of the 1945 Constitution to the enactment of the Soeharto regime, the 1945 Constitution as the constitutional basis of State of Indonesia have not been changed for perfection. Article 1 (3) of the 1945 Constitution states that "Indonesia is a country of law." The 
INTERNATIONAL JOURNAL OF ACADEMIC RESEARCH IN BUSINESS AND SOCIAL SCIENCES Vol. 8, No. 9, Sept. 2018, E-ISSN: 2222-6990 @ 2018 HRMARS

provision of the article is a constitutional basis that Indonesia is a state based on law, the law is placed at the highest position in the society, nation, and state (supremacy of law).

In the course of Indonesia's history, the proclamation of Indonesian independence on 17 August 1945 is a historical event as well as a source of law for the establishment of the Republic of Indonesia. Nevertheless, the proclamation of independence is not the final destination of Indonesia's state, yet a means to achieve its goal to realize prosperous and justice society based on Pancasila as stated in the 1945 opening, paragraph IV. According to Kansil, the proclamation of Indonesian independence is broadly defined as a) The birth of the Republic of Indonesia, b) The point of culmination of Indonesian independence movement, after struggling for decades since May 20, 1908, and c) The starting point on the implementation of the Message of People Suffering. The Indonesian history government started since Indonesia proclaimed its independence on August 17, 1945.

The history of the birth of Indonesian nation government has started since Indonesia has not proclaimed even before independence. On April 29, 1945, the Government of Japan in Jakarta, formed a body referred to "Dokuritsu Juunbi Coosakai" or "Investigation Agency Efforts Preparation of Indonesian Independence " (BPUPKI), this body consists of 62 members, led by Dr. Radjiman Wedyodiningrat. Indonesia government principle is contained in Indonesia Basic Law Constitution) 1945 and for Indonesia, the history of its reign came into force as the implementation of the first Constitution of Constitution of the State of Indonesia in 1945 which entered into force on 18 August 1945 or the day after proclamation of independence of the Republic of Indonesia.

BPUPKI has institute has performed twice meeting: on May 29 until June 1, 1945, and July 10 to July 16, 1945. In performing its duties as the investigative efforts of Indonesian independence, BPUPKI formed a small committee tasked to formulate the results of the agency's negotiations. A small committee consisting of nine members was finally on June 22, 1945, managed to draft the Preamble of the Constitution of 1945. In addition, BPUPKI also has managed to compile a draft of the Republic of Indonesia constitution.

Having successfully established a draft of the Basic Law, the agency finally dissolved and instead formed a new body called the Committee for Indonesian Independence (PPKI) on August 9, 1945.

An agency called PPKI is composed of well-known leaders and people who have and represent regions of Indonesia. The body is therefore considered as a Representative Body, which represents all the people of Indonesia. The day after the reading of the Proclamation of Independence of the Republic of Indonesia, on August 18, 1945, PPKI convened and finally managed to set the following points:

a. The Preamble to the Constitution of 1945.

b. Constitution of 1945.

c. Electing Ir. Soekarno and Drs. Moh. Hatta respectively as President and Vice President of the Republic of Indonesia.

d. President, for the time being, is assisted by the entire National Committee 
INTERNATIONAL JOURNAL OF ACADEMIC RESEARCH IN BUSINESS AND SOCIAL SCIENCES

Vol. 8, No. 9, Sept. 2018, E-ISSN: 2222-6990 @ 2018 HRMARS

\section{Literature Review}

Abu Tamrin (2015) in his study has discussed constitutional changes and constitutional reform in Indonesia. The review is the basic legal issue contained in article 37 of the 1945 Constitution. In its provisions, before the amendment to amend the 1945 Constitution, there is no political consideration from the People's Consultative Assembly to amend the 1945 Constitution. Furthermore, for the Implementation of one layer elements in the reform era. Amendment of the 1945 Constitution. With the amendment of the 1945 Constitution, there is a constitutional reform in Indonesia.

Research conducted by Zulqadri Anan (2013), states that the implications of the amendment of the 1945 Constitution affect the state administration system. The implications are normative by placing primary and secondary legal material as a reference. Investigation in the study shows that there are real implications in the constitutional system in the form of changes in various areas of state life. The change positively led to the establishment of a more democratic Indonesian state. Given the implications of the 1945 Constitution, it is expected to bring the nation towards the better, according to our shared ideals.

Furthermore, Wijayanti (2013) states that the Political Legislation is the direction of the policy of the House of Representatives and the Government in the framework of establishing the relationship of nation and state. The Bill as a political product in a national institution program turned into a legal product when the Bill was changed into law at the time it was ratified. The existence of a law can be a legal product that can fulfill justice for the people in structuring the law.

\section{Results and Discussion}

\section{Indonesia is the State of Law}

Reformation taking place in Indonesia in 1998 has led to a very big change for the nation including in administration of Indonesia. One of the reformation outcomes in the field of administration is four times amendment of the 1945 Constitution. Since the promulgation of Presidential Decree on July 5, 1959 , on the re-enactment of the 1945 Constitution to the enactment of the Soeharto regime, the 1945 Constitution as the constitutional basis of State of Indonesia have not been changed for perfection.

With the Reformation, including reformation in public administration, the desire to perfect the Constitution enhance 195 as something switched so far can be accommodated. Basically, 1945 constitution set in the day after the proclamation of Indonesian independence is temporary and therefore needs to be improved and supplemented.

Article 1 (3) of the 1945 Constitution states that "Indonesia is a country of law." The provision of the article is a constitutional basis that Indonesia is a state based on law, the law is placed at the highest position in the society, nation, and state (supremacy of law).

In the er before the amendment of the 1945 Constitution, the constitutional basis of Indonesia that it is a state based on law is contained in the preamble of 1945 constitution body with the constitutional structure as follows : 


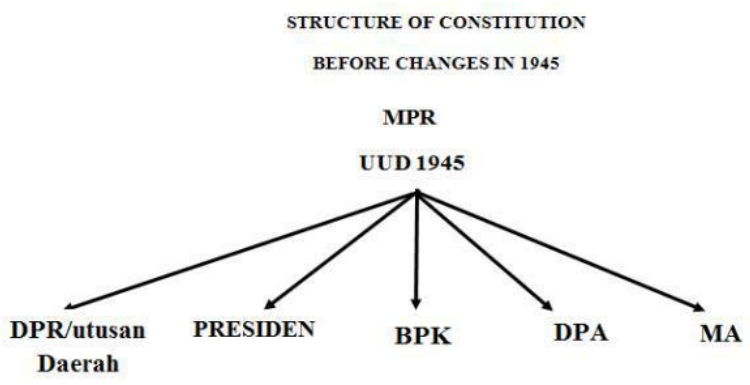

Moreover, a statement that Indonesia is a state of law can also be seen in 1945 explanation, stating that State administration system, namely:

a. Indonesia is a country based on law (rechtstaat) and not based on power (maachtstaat)

b. Constitutional system

c. The highest authority is in the hands of the People's Consultative Assembly (MPR)

d. President is the highest state of governance under the MPR

Based on the first point of the explanation, it is clear that the law is a good order of the national life in the political, economic, social, cultural, and defense and security aspects. Before 1945 Constitution the change and after the change, some constitutions have been applied in Indonesia including Constitution of 1950 and Constitution of the United Republic of Indonesia. The various kinds of constitutions indicate that Indonesia remains a country that is based on the law until the implementation of 1945 amendments as stated in Article 1 (3).

Law in the life of society, nation and state has a function as a control and guide (signs) of people's lives, with the intention to create the order of life of the nation that is safe, orderly, fair, with the guarantee of legal certainty and the protection of human rights. In addition, the law also serves as a source of law in conflict resolution that occurs between the subject of law.

Indonesia remains as a state based on the law to the enactment of the 1945 amendments, as stated in Article 1 (3) mentioned above, the structure of state administration is as follow:

STRUCTURE OF CONSTITUTION

AFTER CHANGES ON CONSTITUTION 1945

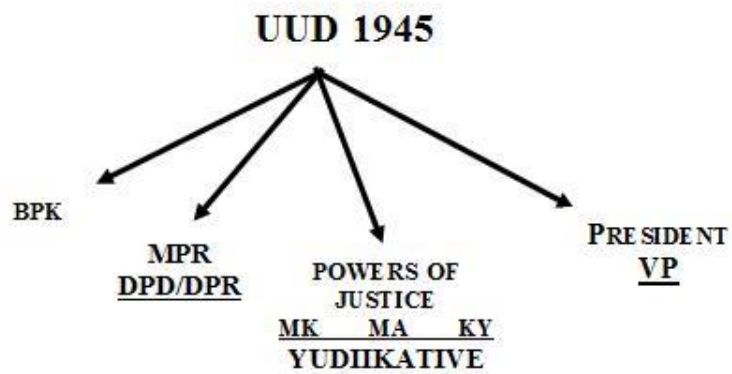


INTERNATIONAL JOURNAL OF ACADEMIC RESEARCH IN BUSINESS AND SOCIAL SCIENCES

Vol. 8, No. 9, Sept. 2018, E-ISSN: 2222-6990 @ 2018 HRMARS

Information:

$\begin{array}{ll}\text { MPR } & \text { : People's Consultative Assembly } \\ \text { DPD } & \text { : House of Representatives } \\ \text { DPR } & \text { : House of Representatives Constitution } \\ \text { BPK } & \text { : Financial Supervision Authority } \\ \text { DPD } & \text { : Regional Representative Council } \\ \text { MK } & \text { : Constitutional Court } \\ \text { MA } & \text { : Supreme Court } \\ \text { KY } & \text { : Judicial Commission }\end{array}$

Characteristics of state of law, and specifically to the state of Indonesian law are known by 1945 Constitution which is the constitutional basis of the Indonesian Legal State. The nature and characteristics of a state of law can be explained by the results of a symposium organized by the University of Indonesia in 1966 in Jakarta. In the symposium stated that:

"The nature of the legal state is where the tool equipment can only act according to and bound by the rules that have been determined in advance using equipment that is authorized to conduct rules or simply called the principle of "the rule of law."

\section{Indonesian State Government System}

According to Prof. R. Djokosutono, $\mathrm{SH}$, a state is a human organization or a collection of human beings who are under the same government. This government is a tool for the people are acting in the interests of the state in achieving organizational goals. In running the government, a system is needed to achieve what can be achieved. The system is a whole, consisting of several parts that have a functional relationship to the totality, thus causing a dependency relationship between the parts. Thus, if one part is not working properly, it will affect the whole of the section.

The government can be interpreted in two meanings, namely government administration in the narrow sense and in a broad sense. Governance in the broad sense is all the affairs conducted by the state in carrying out the people's welfare and interests of his own country, while the government in the narrow sense is a task that only government runs the executive power. Thus in the system of government, how the division of power and relations between state institutions exercise power in a country to carry out the people's interests is also discussed.

In a parliamentary system there is a close relationship between representative bodies or commonly referred to parliament by the executive body. This happens because of a lack of accountability all the action of the Minister to the representative body (parliament), then any cabinet formed must obtain the support of the parliament with a majority vote and all government policies, or cabinet should not deviate from what is established by Parliament. Principles of parliamentary government system include:

a. Head of State is not positioned as head of government since it merely as a national symbol.

b. Government is carried out by a cabinet led by the Prime Minister.

c. The Cabinet is accountable to and can be imposed by Parliament with a motion (therefore) the position of the executive (cabinet) is lower than (and dependent on) the parliament.

\section{Until Now (After Amendments)}

One of the reformation outcomes in the field of administration is four times amendment of the 1945 Constitution. Since the promulgation of Presidential Decree on July 5, 1959, on the re-enactment of the 1945 Constitution to the enactment of the Soeharto regime, the 1945 Constitution as the 
constitutional basis of State of Indonesia have not been changed for perfection. This happens as the New Order era, committed to implement the 1945 Constitution purely and consistently, thus giving the impression that 1945 is one that is "sacred" and cannot be changed by anyone, as well as threats and stigma subversive for anyone who is trying to change the 1945 Constitution because at that time only a new order of government is entitled to interpret the Constitution, 1945.

It looks very ironic as because in 1945 constitution body, particularly Article 37 of the 1945 Constitution provides chance on changes to the 1945 Constitution with rules that have been set clearly. However, it was "vanished" by the issuance of MPR Decree No. I / MPR / 1983 jo MPR Decree No. VII / MPR / 1988 jo Law No. 5 of 1985 on Referendum. With the Reformation, including reformation in public administration, the desire to perfect the Constitution enhance 1945 as something switched so far can be accommodated. Basically, 1945 constitution set in the day after the proclamation of Indonesian independence is temporary and therefore needs to be improved and supplemented. In the Constitution amendment, MPR factions agreed on a few things that do not a concern and disturbing existence of the state. The contents of the agreement are (Huda, 2003).

a. Does not change the 1945 preamble.

b. Defending the Unitary State of the Republic of Indonesia.

c. Reinforce the presidential government system.

d. Abolition of 1945 explanation, and include normative matters of explanation in chapters in the body of 1945.

e. The amendment is made by addendum.

The amendment of the 1945 Constitution also affects the governance system prevailing in Indonesia. It is contained in one of the agreements is to reinforce the constitutional changes of a presidential government system that aims to further strengthen the system of stable and democratic government. According to Jimly Asshiddiqie in his book "Politics of Indonesian State (Study on Amendment 1945)" as quoted by Ni'matul Huda, reinforcement of the presidential system of government after governmental principle is:

a. President and Vice President is the organizer of the state supreme executive power under the Constitution.

b. President and Vice President shall be elected directly by the people, and therefore politically President is no longer accountable to the Assembly, yet to the people who elect.

c. President and/or Vice President can be held accountable in law if the President and/or Vice President have violated the law and the constitution, the implementation of the liability was held in front of the Constitutional Court.

d. Minister is the assistant of the President who is appointed and dismissed by the President, the Minister responsible to the President and not to Parliament.

e. To limit President power and to ensure the stability of the government, it is determined the President period should not be more than two terms.

Regarding the form of government of the Democratic Republic of Indonesia stipulated in Article 1 (2) Amendments to the three laws of the Republic of Indonesia in 1945 which states that: "Sovereignty belonged to the people and carried out in accordance with the Constitution."

The article contained the meaning of democracy as a government of the people, by the people and for the people, or in other words that the highest authority in a country is in the hands of the people. 
INTERNATIONAL JOURNAL OF ACADEMIC RESEARCH IN BUSINESS AND SOCIAL SCIENCES Vol. 8, No. 9, Sept. 2018, E-ISSN: 2222-6990 @ 2018 HRMARS

So it is clear that under the provisions of the 1945 Constitution, Article 1 (2), the State of Indonesia in the form of government of the Democratic Republic.

In addition to the above, the amendments made to the 1945 constitution also resulted in a shift in the President's power in shaping Act, it is stipulated in Article 5 (1) of the 1945 post-amendment which states: "The President is entitled to propose draft Act to the House of Representatives." While the Parliament based on Article 20 (1) of 1945 after the amendment has the power to shape the Act. Thus, the changes to this article lead to domination transitional legislative authority of the President to the House hand. With the change of authority in the form of this law, then there is a change in the power-sharing system (Distribution of power) with MPR supremacy is, to the separation of powers (Separation of power) with the principle of checks and balances. It is also proof of their desire to strengthen the presidential system in the state administration system in Indonesia.

\section{Conclusion}

Amendment of 1945 constitution has a great influence on the change of the constitutional system in Indonesia, including changes in the structure of state administration aimed at the improvement of the Constitution 1945 in order to become basic law the Indonesian nation corresponding with their rapidly developing era and to meet the needs of the people of Indonesia. The amendment from a state based on the law on the structure of the constitution before and after the amendment to the amendment will have an impact on Indonesia as a state of law. In addition to the changes in 1945 are also expected to create stability of national and realize the ideals of the Indonesian Nation to create a fair and justice society based on Pancasila. Article 1 (2) the third Amendments the Republic of Indonesia 1945 constitution states that: "Sovereignty belonged to the people and carried out in accordance with the Constitution."

\section{References}

Tamrin, A. (2015). Perubahan Konstitusi dan Reformasi Ketatanegaraan Indonesia. Jurnal Cita Hukum, 2(1).

Kansil, C.S.T. (1984). Hukum Tata Negara Republik Indonesia. Jakarta: Bina Aksara.

Asshiddiqie, J. (2005). Peradilan Etik dan Etika Konstitusi. Jakarta Timur: Sinar Grafika.

Huda, N. (2003). Politik ketatanegaraan Indonesia: kajian terhadap dinamika perubahan UUD 1945. Yogyakarta: FH UII Press.

Djokosutono, R. (1966). Ilmu negara; himpunan kuliah Prof. Djokosutono. Jakarta: Universitas Indonesia.

Wijayanti, W. (2013). Eksistensi Undang-Undang Sebagai Produk Hukum dalam Pemenuhan Keadilan bagi Rakyat. Jurnal Konstitusi, 10 (1).

Anand, Z. (2013). Implikasi Perubahan Undang-Undang Dasar 1945 Terhadap Sistem Ketatanegaraan Indonesia. Fiat Justitia Jurnal IImu Hukum, 7 (3), 1978-5186. 